This item was submitted to Loughborough's Research Repository by the author.

Items in Figshare are protected by copyright, with all rights reserved, unless otherwise indicated.

\title{
Investigating brand image transfer in sport sponsorship of a participation sport event in Singapore
}

\section{PLEASE CITE THE PUBLISHED VERSION}

https://doi.org/10.3727/152599518X15403853721240

\section{PUBLISHER}

(c) Cognizant Communication Corporation

\section{VERSION}

AM (Accepted Manuscript)

\section{PUBLISHER STATEMENT}

This paper was accepted for publication in the journal Event Management and the definitive published version is available at https://doi.org/10.3727/152599518X15403853721240.

\section{LICENCE}

\section{All Rights Reserved}

\section{REPOSITORY RECORD}

Chiu, Cheryl, and Do Young Pyun. 2019. "Investigating Brand Image Transfer in Sport Sponsorship of a Participation Sport Event in Singapore”. Loughborough University. https://hdl.handle.net/2134/35003. 
Running Head: IMAGE TRANSFER IN PARTICIPATION SPORT EVENT

Investigating Brand Image Transfer in Sport Sponsorship of a Participation Sport Event in Singapore 


\begin{abstract}
The interest from corporate sponsors in participation sport events in Singapore has increased. This study explores the applicability of the model for brand image transfer (Martensen et al., 2007) in a local participation sport event as to whether sponsor-event congruence, event emotions and attitude still work as driving variables for brand image transfer. The data were collected from 224 event participants (aged from 16 to 40) at Surf $n$ Sweat which was Singapore’s biggest beach running event. The questionnaire consisted of the items measuring sponsor-event congruence, event emotions, attitude towards the event, attitude towards the sponsor, and purchase intention. A structural equation modeling supports an adequate overall and internal fit of the model to the data. The path analysis shows that sponsor-event congruence significantly influenced positive event emotions $(\beta=.31)$, positive event emotions significantly influenced attitude towards the event $(\beta=.73)$, event attitude significantly influenced attitude towards the sponsor $(\beta=.33)$, and sponsor attitude significantly influenced purchase intention $(\beta=.82)$. However negative event emotion did not mediate the relationship between sponsor-event congruence and event attitude. The findings provide empirical evidence of consumer behaviour in brand image transfer, thereby benefiting corporate sponsors looking to explore event sponsorship for their brand marketing in Singapore.
\end{abstract}

Keywords: brand image transfer, event emotion, attitude towards the event, attitude towards the sponsor, purchase intention, structural equation modeling 


\section{Introduction}

Over the years, sponsorship has been popularly utilised as a key marketing tool in the sport industry. Worldwide sponsorship expenditure reached $\$ 62.8$ billion in 2017, a 4.5 percent increase from 60.1 billion in 2011 (IEG, 2017). The changes in consumer reactions and constraints in advertising have led marketers to choose sponsorship over traditional advertising. Consumers perceive traditional advertising as an interruption mode, resulting in an increasing consumers' defense mechanism whilst sponsorship is regarded as a passion mode, which lowers consumers’ defense mechanisms (Cameron, 2009). Other advertising constraints include advertising clutter (Sneath, Finney, \& Close, 2005), restrictions on advertising (Olson, 2010) and higher advertising costs (Shank, 2009). The reasons companies engage in sponsorship vary, including increasing brand awareness, building brand image, boosting sales, strengthening client relationships, stimulating product trial and leveraging media for exposure due to the increased media coverage of sponsored events (e.g., Crompton, 2004; Fetchko \& Roy, 2013; Gwinner \& Bennett, 2008; Verity, 2002). Of these reasons, practitioners have ranked the increase in brand image as a key objective for sponsorship (e.g., Cornwell, Roy, \& Steinard, 2001; Grohs \& Reisinger, 2014; Grohs, Wagner, \& Vsetecka, 2004; Gwinner, 1997).

Event sponsorship is an attractive form of marketing communication (Rajdeep \& Subhadip, 2013). It is a part of a broader concept of experiential marketing (Martensen \& Grønholdt, 2008) which refers to "the creation of a multisensory, interactive environment by a sports property or sponsor, designed to add value to a consumer's experience in the short term and strengthen relationships in the long term” (Fetchko \& Roy, 2013, p. 177). As events involve their target groups, a high level of participant engagement is expected, providing the target group an experience that appeals to their feelings, emotions and senses (Martensen \& Grønholdt, 2008). Such an event's positive images could be transferred to a sponsor through 
the sponsorship activity (Martensen \& Grønholdt, 2008). The important assumption behind this concept is that the similarity in meaning between a sport event and a sponsor would influence consumers' affective (e.g., emotion, attitude) and behavioural (e.g., purchase intention) outcomes. Thus, one important criterion for a sponsor when choosing a sport event is whether the sport property shares similar meanings with the sponsor so as to increase the effectiveness of sponsorship activity (Fortunato, 2013).

The exponentially increasing popularity of participation events worldwide has caught the attention of corporate sponsors (Ward, 2017). One considerable objective for companies engaging in event sponsorship is the opportunity to leverage the event and its participants for brand image transfer (Mullin, Hardy, \& Sutton, 2007). Brand image transfer represents "the transfer of associations attributed to the sponsored activity to the sponsoring brand" (Grohs, Wagner, \& Vsetecka, 2004, p. 123). The theoretical justification supporting the concept of brand image transfer is explained by "schema-based response to marketing communication” which is on basis of priori knowledge of stimuli learned from previous experience and information in attending an event (McDaniel, 1999, p. 164). Such schemas related to the event may cause consumers to respond to sponsorship activities in different ways (McDaniel, 1999). Though a plethora on literature in brand image transfer through event sponsorship have been found, scarce attention has been paid to testing of its applicability in various contexts (Novais \& Arcodia, 2013).

In Singapore, various participation running events, ranging from competitive runs (e.g., Army Half Marathon) to fun runs (e.g., Hello Kitty Run), have seen a surge in popularity, from 55 running events in 2012 to 76 in 2014 (Ang, 2014). The rise in numbers of runs has also seen a rise in demand for sponsors supporting the events (Ang, 2014). On the other hand, the vast types of running events make it more careful for sponsors to decide which outlets enable them to achieve the desired synergy with the participants and their brand (Ang, 2014). 
This study therefore aims to supplement sponsors in their decision-making process in sponsorship in a sport event.

Martensen, Grønholdt, Bendtsen, and Jensen (2007) conceptualised the comprehensive model for the effectiveness of event marketing, proposing brand/event related routes to explain consumer behaviour. In this study, the applicability of the event related route was tested on a participation event in Singapore. In particular, this study was purported to investigate sponsor image transfer from sponsor-event congruence to sponsor attitude and thereafter purchase intention of the sponsor's products. Emotions and event attitude as driving domains were also included in the model. Aside from adding on to current literature on the image transfer and understanding of consumer behaviour, this study would provide empirical evidence for sponsors looking to explore the extent of brand image transfer in even sponsorship for their brands in Singapore.

\section{Literature Review}

An early investigation on brand image transfer was found in McCracken (1989) conceptualising meaning transfer in celebrity endorsement. Since then many scholars have apply this concept of image transfer in various sport contexts. For instance, Gwinner (1997) adapted the McCracken's (1989) concepts and tested the relationship between image transfer and behaviour intention of sponsors' products among American football fans. Other relevant works (e.g., Franzen \& Bouwman, 2001; Hansen, 2005; Hansen, Martensen, \& Christensen, 2005; Heath, 2001) view brand image transfer as an advertising/sponsorship communication process and examined how information processing among consumers occur.

More recently, Martensen et al. (2007) developed the model of event effectiveness which was extended from the existing literature in various domains concerning drivers of sponsorship value, consumer choice with regards to brand advertising, the effects of advertising on the mind and neuropsychological theory. Grounded on the model of Martensen 
et al. (2007), this study is concerned with attitude towards the event and emotional responses derived by image congruence in sport sponsorship. The proposed model illustrates how various constructs interact to form a consumer's information processing and introduces two ways in creating sponsor attitude and purchase intention of the sponsors to explain the sponsorship effectiveness. The central and peripheral routes focus on the sponsor's brand and event related experience, respectively, where the routes are related through different emotions as well as attitude about the event people form (Martensen \& Grønholdt, 2008).

The link between emotions and attitudes was based on the hypothesis that emotions towards the event can influence "nature of the parallel central brand information processing" where positive emotions regarding the event could lead to favourable attitude towards sponsor and negative event emotions would negatively form the attitude (Martensen \& Grønholdt, 2008, p. 48). This association is seen as "the value transfer or the spill-over effect the event may have on the brand itself, so that the consumer's perception of the event helps create or change the preference toward the brand" (Martensen \& Grønholdt, 2008, p. 48). It was concluded that brand involvement, brand-event congruence and event involvement each created positive or negative emotions which then affected brand and event attitudes, in turn, purchase intention (Martensen et al., 2007). While this model was initially developed on a

golf event sponsored by the Danish corporate, there has been no further evidence to support if this model still works for consumers in other cultures and other sporting event types. Hence this study was designed to apply the model to a local participation event in Singapore and provide empirical support to establish its external validity.

\section{Congruence Between Sponsor and Event}

The term sponsor-event congruence is described by various literature as relevance, relatedness, compatibility and consistency in terms of meanings between s sport property and a sponsor (e.g., Martensen \& Grønholdt, 2008; Pham \& Johar, 2001; Rifon, Choi, Trimble, \& 
Li, 2004; Ruth \& Simonin, 2003). A common finding from past literature is that sponsor-event congruence is a significant indicator in predicting attitude towards the sponsor and increasing the possibility of a favorable image transfer within people’ minds (e.g., Grohs \& Reisinger, 2014; Martensen et al., 2007; Novais \& Arcodia, 2013; Olson, 2010; Speed \& Thompson, 2000; Weeks, Cornwell, \& Drennan, 2008). As consumers tend to associate their attitudes towards an event with the sponsoring brand (Keller, 1993), positive images invoked through a successful event can be transferred to the sponsoring brand (c.f., McDaniel, 1999). The level of perceived sponsor-event congruence has also been found to influence consumer beliefs, emotion and behavioural intentions (Becker-Olsen, 2003; Martensen \& Grønholdt, 2008). A good fit was found to have a significant impact on emotions (Martensen et al., 2007). If the participants perceive a logical link, the brand's communication message will appear consistent and reliable, so a successful event would invoke positive emotions among participants, or vice versa. The following hypotheses were established:

Hypothesis 1: There would be a negative impact of brand-event congruence on negative event emotions.

Hypothesis 2: There would be a positive impact of brand-event congruence on positive event emotions.

\section{Positive and Negative Event Emotions}

People may show emotional and attitudinal reactions differently toward different sponsors (Hansen et al., 2005). Emotions refer to “unconscious underlying elementary processes” (Du Plessis, 2005, p. 84). Consumer emotions determine whether a person reacts to a certain stimulus (Oatley \& Jenkins, 1995). A consumer’s different emotions to a stimulus (e.g., ancillary activity, hospitality, food, etc.) determines whether s/he would drive his or her attention further to a certain stimulus (e.g., agreeing to join the ancillary activity if asked; Oatley \& Jenkins, 1995). As explained earlier, brand image transfer is popularly seen as an 
advertising communication process. According to Holbrook and Batra’s (1987) advertising communication model, emotion plays as a mediator in the relation between advertising exposure and attitude towards advertising. In the context of sport sponsorship, Holbrook and Batra's (1987) emotional responses can be seen as event emotions, and advertising exposure can be seen as sponsor activations during the event while attitude towards the advertisement can be seen as attitude towards the event. Through emotional response on external stimuli, consumers make a logical evaluation of the event and builds their attitude towards the event (Martensen \& Grønholdt, 2008). In other words, exposure to an event arouses event emotions which then results in the consumer forming an attitude towards the event. Thus, two related hypotheses for event emotions and attitude towards the event were proposed:

Hypothesis 3: There would be a positive impact of positive event emotions on attitude towards the event.

Hypothesis 4: There would be a negative impact of negative event emotions on attitude towards the event.

\section{Proposed Relationships among Attitude towards the Event, Attitude towards the Sponsor and Purchase Intention}

Attitude towards event hypothesises that "consumer attitude towards an event represents an accumulation of individual experience with that event over time” (Ashill, Davies, \& Joe, 2001, p. 29-30). The relationship between an event and a sponsor attitudes represents how much people link experience and information obtained from the event to their attitude towards the sponsor (Martensen \& Grønholdt, 2008; Speed \& Thompson, 2000). Gwinner and Eaton (1999) highlighted that the image transfer would be stronger between a sport property and a sponsor when they have similar image meaning-based linkage and, in turn, influences consumers' consumption behaviour. Martensen et al. (2007) added the empirical evidence 
supporting a positive relationship between event and sponsor attitude $(\beta=.42)$ during the Danish golf tournament.

In sponsorship, the construct of consumers' purchase intention is considered one of the most significant indicators when evaluating the sponsorship effectiveness (Crompton, 2004). Past literature has found that a positive sponsor (or brand) attitude had a positive influence on buying intention (e.g., Biscaia, Correia, Rosado, Ross, \& Maroco, 2013; Carrillat, Lafferty, \& Harris, 2005; Close, Finney, Lacey \& Sneath, 2006; McDaniel, 1999; Speed \& Thompson, 2000; Verity 2002). For instance, Biscaia et al. (2013) showed the direct positive impact of attitudes toward the sponsor on purchase intention of sponsors' products of in the top Portuguese football league ( $\beta=.72$ for sponsor $\mathrm{A}$ and $\beta=.76$ for sponsor $\mathrm{B}$ ), which were the strongest coefficients in their structural model. Therefore, we hypothesised as follows:

Hypothesis 5: There would be a positive impact of attitude towards the event on attitude towards the sponsor.

Hypothesis 6: There would be a positive impact of attitude towards the sponsor on purchase intentions of the sponsor's products

In Summary, the proposed model shown in Figure 1 was adapted from Martensen et al.’s (2007) hypotheses for the effectiveness of event sponsorship. The model contains six constructs and predict consumption behaviour using various indicators (i.e., sponsor attitude, event attitude and event emotions) which are influenced by sponsor-event match. Figure 1 show the proposed relationships discussed earlier among the constructs.

\#\#\#Insert Figure 1 around here\#\#\#

\section{Research Participants}

\section{Method}

Surf n Sweat is Singapore's biggest participatory beach event organised by the sport club at a large university in the western Singapore. This annual event consists of a fun run together with various ancillary games which span one entire day. There were approximately 
1,600 participants in the 2015 event, where data collections for this study were made. Red Bull was the main official sponsor and had the highest level of activation among other sponsors during the event. The objective of Red Bull in sponsoring this event was to form a positive sponsor attitude and image among their target audience, young adults.

Of the 237 questionnaires distributed to participants during the event using convenience sampling, 224 valid questionnaires were utilised in data analyses after 13 insincerely and/or incompletely answered questionnaires were eliminated (94.5\% response rate). The respondents comprised 88 males (39.3\%) and 136 females (60.7\%). A large majority of the subjects were Chinese (84.8\%), followed by Malay (10.7\%), Indian (1.79\%) and other ethnic groups (2.68\%). Around two-thirds of the participants (66.1\%) were aged from 21 to 30 years old, 31.3\% was aged from 16 to 20 years old, and 2.68\% was aged from 31 to 40 years old. On average, $82.1 \%$ of the participants had taken part in participation sport events at least once a year.

\section{Data Collection Procedure}

Permission was obtained from the senior co-chairperson of the event organising committee beforehand of data collection. Data were collected using self-administered questionnaires which were handed out to participants who were waiting for the start of their next events or already completed their event and were resting. The participants were advised to read all information and encouraged to ask questions if necessary. The questionnaires took about five minutes to complete. The research procedures were cleared by the Institutional Review Board. In addition, parents’ consent was obtained for participants younger than 18.

\section{Instrument Development}

The questionnaire consisted of six sections. The first section was designed to measure the participants' evaluation of sponsor-event congruence (e.g., between Red Bull and Surf n Sweat) with five items adapted from Martensen et al. (2007). The second section consisted of 
16 items for both positive and negative event emotions (e.g., how they felt about Surfn Sweat), developed by Hansen (2005). Of the items, nine were of positive emotions while seven were of negative emotions. The third section was to measure participants' attitude towards the sponsor with nine item which were developed on the basis of past literature on brand equity and brand credibility (Ha, 1996; Martensen et al., 2007; Putrevu \& Lord, 1994; Schlinger, 1979). The fourth section measured the participants' attitude towards the event using seven items (Martensen et al., 2007). In addition, four items measuring purchase intention of the sponsor's products (Martensen et al., 2007) were included in the fifth section. All items for the six constructs were measured on a 5-point Likert-type scale, anchored with strongly disagree (1) and strongly agree (5). Participants' demographic characteristics (e.g., gender, race, age, and participation in other participation sport events) were measured in the last section.

\section{Data Analysis}

Using IBM Statistical Package for the Social Sciences (SPSS 22.0), descriptive statistics and internal consistency were examined to inspect missing values, outliers, normality and reliability of the measures. Using LISREL 8.8, the proposed model was assessed with structural equation modeling (SEM) to examine the overall and internal model fit as well as the six hypotheses. An alpha level of .05 was used for all statistical tests.

\section{Results}

\section{Preliminary Analyses}

The preliminary analyses using descriptive statistics reported no outliers or missing values (see Table 1). The assumption of normality of the data was tested using skewness and kurtosis statistics. Skewness and kurtosis values of all items ranged from 0.66 to 1.07 and from -0.87 to 1.39 , respectively, which were within the acceptable range of \pm 2.00 (West, Finch, \& Curran, 1995). Reliability was determined by calculating Cronbach’s alpha 
coefficients of each construct. Table 1 shows Cronbach’s alpha coefficients of the six constructs ranged from .71 to .92; all values were higher than the .70 cut-off (Nunnally \& Bernstein, 1994). It was reported that one item in positive event emotions (i.e., item 4) had its item-total correlation of .24 which was lower than the acceptable level of .50 (Glynn, 2009), thus was removed for the further analyses. As a result, Cronbach's alpha for positive event emotions increased to .72 .

\#\#\#Insert Table 1 around here\#\#\#

\section{Assessment of the Overall and Internal Model Fit}

The measurement model indicated that the chi-square statistic $\left(\chi^{2}=1997.21, d f=773\right)$ was significant $(p<.05)$, resulting in an inadequate fit as this means that the sample covariance matrix differed significantly from the implied covariance matrix (Schumacker \& Lomax, 2010). However, this statistic is usually sensitive to a sample size (Cheung \& Rensvold, 2002). As a sample size increases (generally above 200), a $\chi^{2}$ statistic tends to reject the null hypothesis at 5\% level of significance (Schumacker \& Lomax, 2010). Thus, other approximate fit indexes such as root mean square error of approximation (RMSEA), normed fit index (NFI), and comparative fit index (CFI) were often called upon to assess the adequacy of fit in the measurement model. The value of RMSEA was .08 which fell within the recommended range of .05 to .08 (Schumacker \& Lomax, 2010). In addition, NFI and CFI values were each .92, meeting the proposed .90 cut-off (Kelloway, 1998; Kline, 2011). Overall the model seemed to represent an acceptable fit to the data.

To assess reliability of the measures, the average variance extracted (AVE) values were calculated. AVE values of sponsor-event congruence, sponsor attitude and purchase intention ranging from .54 to .66 met the cut-off of .50 indicating that more than half of the total variance of these measures was explained by their constructs rather than errors (Fornell \& Larcker, 1981). However, positive event emotions, negative event emotions and event attitude 
ranging from .23 to .46 failed to satisfy this cut off (see Table 2). Convergent validity was assessed using factor loadings for all items. Of the 41 items, 21 items showed lack of convergent validity hence, having more unique variance than common variance as they fell below the suggested cut-off of .707 (Kline, 2011; see Table 2).

\#\#\#Insert Table 2 around here\#\#\#

Discriminant validity was assessed by comparing if the square root of AVE for a construct is higher than the construct's correlations with other constructs in the model (Fornell \& Larcker, 1981; Hulland, 1999). The AVE square roots and construct correlations in Table 3 reveals that there was lack of discriminant validity between positive event emotions and attitude towards the event and between attitude towards the sponsor and purchase intention. The other relations between AVEs and correlations among constructs supported discriminant validity. \#\#\#Insert Table 3 around here\#\#\#

\section{Hypotheses Testing Using Structural Equation Modelling}

Using a structural model, the six hypotheses were tested. Table 4 shows that sponsorevent congruence significantly influenced positive event emotions $(\beta=.31, p<.01)$; positive event emotions significantly influenced event attitude $(\beta=.73, p<.01)$; event attitude significantly influenced sponsor attitude $(\beta=.33, p<.01)$; and sponsor attitude significantly influenced purchase intention $(\beta=.82, p<.01)$. Hypotheses $2,3,5$ and 6 were supported at the .05 probability level. There was a relatively higher level of model explanatory power with $68 \%$ of the total variance of purchase intention explained by the model $\left(R^{2}=.68\right)$ and $54 \%$ of the total variance of event attitude explained by the model $\left(R^{2}=.54\right)$. The $R^{2}$ value of sponsor attitude was quite low, indicating that the model was able to explain $11 \%$ of what drives sponsor attitude, with $89 \%$ unexplained error variance due to random or systematic error and variables not in the model (see Table 4). However, the tests revealed that there were no significant relationships between sponsor-event congruence and negative event emotions $(\beta$ 
$=.08, p=.29)$ and between negative event emotions and event attitude $(\beta=.08, p=.20)$, failing to support $\mathrm{H} 1$ and $\mathrm{H} 4$ at the .05 probability level.

\#\#\#Insert Table 4 around here\#\#\#

\section{Discussion}

\section{Summary and Explanations of Findings}

The purpose of this study was to test sponsor -event congruence, event emotions and attitude as driving factors in the brand image transfer process through Red Bull's sponsorship of Surf n Sweat. This study applied Martensen et al.’s (2007) event related route for brand image transfer in the novel context of a participation sporting event in Singapore.

Hypothesis 2 which proposed that sponsor-event congruence would positively influence positive event emotions was supported. This finding was widely supported by several past studies that perceived sponsor-event congruence has been found as an important indicator of consumer emotions surrounding an event (Becker-Olsen, 2003; Martensen et al., 2007; Martensen \& Grønholdt, 2008). According to Mullin et al. (2007), one possible reason supporting this relation is that people are getting 'less formidable' when they perceive a congruence between two. Hypothesis 3 which stated that positive event emotions would have a positive effect on attitude towards the event was also supported. This finding was in line with Martensen et al.’s (2007) study. Even in the different context of a local participation sport event, the higher the sponsor-event match, the higher the positive event emotions. Also, the higher the positive event emotions, the higher the positive effect on attitude towards the event. However, the image match between Red Bull and Surf n Sweat did not negatively affect negative event emotions. This finding was inconsistent with the previous literature revealing that consumers develop negative psychological tensions and emotions when they are not able to see an appropriate fit between sponsor and event (Woisetschläger \& Michaelis, 2012). Another notable finding was such negative event emotions did not significantly predict 
attitude towards the event. Hence, $\mathrm{H} 1$ and $\mathrm{H} 4$ were not supported. A plausible explanation for this would be that Surf $n$ Sweat already had an established image due to its long history. Most participants might have had a preconceived positive conception of the event. Regardless of sponsor-event match, participants' may not associate negative emotions with the event. For the same reason, negative event emotions would not significantly influence attitude toward the event. With regard to H5, it was found that attitude towards the attitude had a positive effect on attitude towards the sponsor. This finding was also supported by previous literature (Martensen et al., 2007; McDaniel, 1999). When people have higher the event attitude, they tend to show a higher positive effect on the brand attitude. Hypothesis 6, which proposed that sponsor attitude had a positive effect on purchase intention, was also supported. Various literature and empirical studies have also found that brand attitude had a significant positive influence on purchase intention (Carrillat et al., 2005; Close et al., 2006; McDaniel, 1999; Speed \& Thompson, 2000; Verity 2002).

Compared to Martensen et al.’s (2007) application of the model on a competitive golf event, this study applied the model on a beach event which consisted of a non-competitive fun run and carnival games. The results of this study concluded that the model showed adequate overall and internal fit and can be applied to the said context. sponsor-event congruence, positive event emotions and event attitude were key driving variables in the brand image transfer process. Corporate sponsors looking to explore the extent of brand image transfer in a sponsorship of an event for their brands in Singapore should note the crucial role of sponsorevent congruence. Sport marketers need to recognise that meaning transfer occurs from the sport property to the sponsor themselves. Participants usually establish emotional attachment by experiencing sport events they choose to attend (Gwinner \& Swanson, 2003). Sponsors then could expect this positive characteristic of the event participants to be transferred to the behaviour of purchasing products of the sponsor (Fortunato, 2013). Thus, it is important to 
understand dispositions of an event and carefully consider if participants would see a credible consistency between the event activity and the sponsor.

Corporate sponsors are necessary to select events which they are able to see a functional or an image match. Kaynak, Salman, and Tatoglu (2008) highlighted that "organizations use sport as a medium of creating a distinctive image in the eyes of consumers and may in turn distinguish their brand form those of their competitors” (p. 336). Consumers intend to find perceived meaning from its sport (e.g., beach games, tchoukball, volleyball), theme (e.g., fun, young, energy, fiesta), and place (e.g., Sentosa Island, Singapore) and recognise similarities in perceived images and functions between the event and the sponsor's products with the name and the logo of the event. A good fit between the event and the sponsor eventually leads to a set of positive outcomes (e.g., emotion and attitudes). Effective marketing communications would increase the likelihood to link two properties (Grohs \& Reisinger, 2014).

Additionally, it should be understood that the success of the event in creating positive event emotions and positive event attitude plays an important role in positive sponsor image transfer. A well recognised event that has been running annually would already have credibility, reliable standards and even customer loyalty. Asides from the event's history, the success of the event also depends largely on the event organiser. It is therefore important for a company to consider the tradition of the event as well as the experience level and team dynamics of an event's management team when selecting an event to sponsor.

\section{Conclusion}

The study aimed to investigate brand image transfer in sport sponsorship in the context of a participation sporting event in Singapore. The study applied the Martensen et al.’s (2007) event related role for brand image transfer and found to have adequate model fit, supporting the applicability of the model in the Singapore context. Of the constructs in the structural model, sponsor-event congruence, positive event emotions, and event attitude were found to 
be key driving determinants in the brand image transfer process. This study provides empirical evidence of consumer behaviour in brand image transfer, benefiting corporate sponsors looking to explore event sponsorship to enhance their brand image among Singapore consumers. Corporate sponsors could note the importance of sponsor-event congruence and choose to sponsor participation sporting events which they are able to share a functional or an image match.

While the findings provide useful information to practitioner in establishing successful sponsorship design and strategies, several limitations encountered during the development of the study need to be addressed to suggest guidelines for future studies. Firstly, due to the nature of the sport event being organised at a university level, various restrictions on the magnitude of sponsor activations were placed to prevent the event from looking overly commercialised. This rules out certain categories of sponsors that might potentially have a significant contribution to the event (e.g., beer and gambling sponsors). In addition, there would be a possible gap in the application of the findings derived from this mid-size event to other mega participation events. A future study may therefore apply the model to a more commercialised mass participation event (e.g., Standard Chartered Singapore Marathon). Secondly, even though young adults are a significant consumer segment of the sponsor (Red Bull, 2016), the results of the study might have a limited generalisability due to the unique characteristics of the samples. Such recreational sport events often feature participants of a wide range of ages as the low physical requirement and little restrictions on age appeals to people of all ages (Long \& Hylton, 2014). Future research could look into varying events with participants of a wide range of ages (e.g., youths, elderly people). Lastly, this study tested the Martensen et al.'s (2007) model to explore the effectiveness of sponsorship on one single local participation event. Future studies could apply the model on various local contexts such as multisport or specific sport events, competitive/non-competitive events, one-/multiple-day 
events, globally recognised events held locally, or charity runs. In addition, other possible variables such as perceived sincerity, ubiquity, and brand equity of the sponsor as well as the brand's exposure (Novais \& Arcodia, 2013) could be incorporated into the model to better explain the impact of image transfer. 


\section{References}

Ang, B. (2014, September 14). Singapore's race craze draws both fun and serious runners. The Straits Times. Retrieved from http://www.straitstimes.com/lifestyle/more-lifestylestories/story/singapores-race-craze-draws-both-fun-and-serious-runners-2014

Ashill, N. J., Davies, J., \& Joe, A. (2001). Consumer attitudes towards sponsorship: A study of national sports event in New Zealand. International Journal of Sports Marketing and Sponsorship, 2(4), 21-43.

Biscaia, R., Correia, A., Rosado, A. F., Ross, S. D., \& Maroco, J. (2013). Sport sponsorship: The relationship between team loyalty, sponsorship awareness, attitude toward the sponsor, and purchase intentions. Journal of Sport Management, 27(4), 288-302.

Becker-Olsen, K. (2003). And now, a word from our sponsor. Journal of Advertising, 32(2), $17-32$.

Cameron, N. (2009). Understanding sponsorship and its measurement implications. Journal of Sponsorship, 2(2), 131-139.

Carrillat, F. A., Lafferty, B. A. \& Harris, E. G. (2005). Investigating sponsorship effectiveness: Do less familiar brands have an advantage over more familiar brands in single and multiple sponsorship arrangements? Brand Management, 13(1), 50-64.

Cheung, G. W., \& Rensvold, R. B. (2002). Evaluating goodness-of-fit indexes for testing measurement invariance. Structural Equation Modeling, 9(2), 233-255.

Close, A. G., Finney, R., Lacey, R., \& Sneath, J. (2006). Engaging the consumer through event marketing: Linking attendees with the sponsor, community, and brand. Journal of Advertising Research, 46(4), 420-433.

Cornwell, T. B., Roy, D. P., \& Steinard, E. A. (2001). Exploring managers’ perceptions of the impact of sponsorship on brand equity. Journal of Advertising, 30(2), 41-51. 
Crompton, J. L. (2004). Conceptualization and alternative operationalizations of the measurement of sponsorship effectiveness in sport. Leisure Studies, 23(3), 267-281.

Du Plessis, E. (2005). The advertised mind. London: Kogan Page.

Fetchko, M., \& Roy, D. (2013). Sports marketing. Boston: Pearson.

Fornell, C., \& Larcker, D. F. (1981). Evaluating structural equation models with unobservable variables and measurement error. Journal of Marketing Research, 18(1), 39-50.

Fortunato, J. A. (2013). Sports sponsorship: Principles and practices. Jefferson, NC: McFarland \& Company, Inc.

Franzen, G., \& Bouwman, M. (2001). The mental world of brands: Mind, memory and brand success. Henley-on-Thames, UK: World Advertising Research Center.

Glynn, M. S. (2009). Manufacturer brand benefits: Mixed methods scaling. In M. S. Glynn \& A. G. Woodside (Eds.), Business-to-business brand management: Theory, research and executive case study exercises (pp. 33-114). Bingley, UK: Emerald JAI.

Grohs, R., \& Reisinger, H. (2014). Sponsorship effects on brand image: The role of exposure and activity involvement. Journal of Business Research, 67(5), 1018-1025.

Grohs, R., Wagner, U., \& Vsetecka, S. (2004). Assessing the effectiveness of sport sponsorships: An empirical examination. Schmalenbach Business Review, 56(2), 119-138.

Gwinner, K. P. (1997). A model of image creation and image transfer in event sponsorship. International Marketing Review, 14(3), 145-158.

Gwinner, K. P., \& Bennett, G. (2008). The impact of brand cohesiveness and sport identification on brand fit in a sponsorship context. Journal of Sport Management, 22(4), 410-426.

Gwinner, K. P., \& Eaton, J. (1999). Building brand image through event sponsorship: The role of image transfer. Journal of Advertising, 28(4), 47-58. 
Gwinner, K. P., \& Swanson, S. R. (2003). A model of fan identification: Antecedents and sponsorship outcomes. Journal of Services Marketing, 17(3), 275-294.

Ha, L. (1996). Observations: Advertising clutter in consumer magazines: Dimensions and effects. Journal of Advertising Research, 36(1), 76-84.

Hansen, F. (2005). Distinguishing between feelings and emotions in understanding communication effects. Journal of Business Research, 58(10), 1426-1436.

Hansen, F., \& Christensen S. R. (2007). Emotions, advertising and consumer choice. Copenhagen, Denmark: Copenhagen Business School Press.

Hansen, F., Martensen, A., \& Christensen, S. R. (2005). Modelling emotional and attitudinal responses as drivers of sponsorship value. International Journal of Sports Marketing \& Sponsorship, 7(1), 69-74.

Heath, R. (2001). The hidden power of advertising: How low involvement processing influences the way in which we choose brands. Henley on Thames, UK: NTC Publications.

Holbrook, M. B., \& Batra, R. (1987). Assessing the role of emotions as mediators of consumer responses to advertising. Journal of Consumer Research, 14(3), 404-420.

Hulland, J. (1999). Use of partial least squares (PLS) in strategic management research: A review of four recent studies. Strategic Management Journal, 20(2), 195-204.

IEG. (2017). What sponsors want and where dollars will go in 2017. Retrieved from http://www.sponsorship.com/IEG/files/7f/7fd3bb31-2c81-4fe9-8f5d-1c9d7cab1232.pdf

Kaynak, E., Salman, G. G., \& Tatoglu, E. (2008). An integrative framework linking brand associations and brand loyalty in professional sports. Journal of Brand Management, 15(5), 336-357.

Keller, K. (1993). Conceptualising, measuring, and managing customer-based brand equity. Journal of Marketing, 57(1), 1-22. 
Kelloway, E. K. (1998). Educational research, methodology, and measurement: An international handbook. Fairview Park, NY: Pergamon Press.

Kline, R. B. (2011). Principles and practice of structural equation modeling (3rd ed.). New York: The Guilford Press.

Long, J., \& Hylton, K. (2014). Reviewing research evidence and the case of participation in sport and physical recreation by black and minority ethnic communities. Leisure Studies, 33(4), 379-399.

Martensen, A., Grønholdt, L., Bendtsen, L., \& Jensen, M. J. (2007). Application of a model for the effectiveness of event marketing. Journal of Advertising Research, 47(3), 283301.

Martensen, A., \& Grønholdt, L. (2008). How events work: Understanding consumer responses to event marketing. Innovative Marketing, 4(4), 44-56.

McCracken, G. (1989). Who is the celebrity endorser? Cultural foundations of the endorsement process. Journal of Consumer Research, 16(3), 310-321.

McDaniel, D. (1999). An investigation of match-up effects in sport sponsorship advertising: The implications of consumer advertising schemas. Psychology \& Marketing, 16(2), 163-184.

Mullin, B. J., Hardy, S., \& Sutton, W. A. (2007). Sport marketing (3rd ed.). Champaign, IL: Human Kinetics.

Novais, M. A., \& Arcodia, C. (2013). Measuring the effects of event sponsorship: Theoretical frameworks and image transfer models. Journal of Travel \& Tourism Marketing, 30(4), 308-334.

Nunnally, J. C., \& Bernstein, I. H. (1994). Psychometric theory (3rd ed.). New York: McGraw-Hill. 
Oatley, K., \& Jenkins, J. M. (1995). Understanding emotions. Oxford, UK: Blackwell Publishing.

Olson, E. L. (2010). Does sponsorship work in the same way in different sponsorship contexts? European Journal of Marketing, 44(1), 180-199.

Pham, M. T., \& Johar, G. V. (2001). Market prominence biases in sponsor identification: Processes and consequentiality. Psychology \& Marketing, 18(2), 123-143.

Putrevu, S., \& Lord, K. R. (1994). Comparative and noncomparative advertising: Attitudinal effects under cognitive and affective involvement conditions. Journal of Advertising, 23(2), 77-91.

Rajdeep, C., \& Subhadip, R. (2013). Meaning transfer between events and sponsor brands: Integrating the role of emotions - a new conceptual framework. Journal of Brand Strategy, 2(1), 87-105.

Red Bull (2016). Red bull GmbH company report. Retrieved from https://researchmethodology.net/red-bull-gmbh-report/

Schumacker, R. E., \& Lomax, R. G. (2010). A beginner's guide to structural equation modeling (3rd ed.). New York: Routledge.

Rifon, N. J., Choi, S. M., Trimble, C. S., \& Li, H. (2004). Congruence effects in sponsorship. Journal of Advertising, 33(1), 29-42.

Ruth, J. A., \& Simonin, B. L. (2003). Brought to you by brand A and brand B: Investigating multiple sponsors' influence on consumers’ attitudes toward sponsored events. Journal of Advertising, 32(3), 19-30.

Schlinger, J. M. (1979). A profile of responses to commercials. Journal of Advertising Research, 19(2), 37-46.

Shank, M. (2009). Sports marketing: A strategic perspective (4th ed.). Upper Saddle River, NJ: Prentice Hall. 
Sneath, J. Z., Finney, R. Z., \& Close, A. G. (2005). An IMC approach to event marketing: The effects of sponsorship and experience on costumer attitudes. Journal of Advertising Research, 45(4), 373-381.

Speed, R., \& Thompson, P. (2000). Determinants of sports sponsorship response. Journal of the Academy of Marketing Science, 28(2), 226-238.

Verity, J. (2002). Maximising the marketing potential of sponsorship for global brands. European Business Journal, 14(4), 161-174.

Ward, S. (2017, April 26). Authenticity key to successful sponsorships of mass-participation events. Sportcal. Retrieved from http://www.sportcal.com/News/FeaturedNews/110498

Weeks, C. S., Cornwell, T. B., \& Drennan, J. C. (2008). Leveraging sponsorship on the internet: Activation, congruence, and articulation. Psychology and Marketing, 25(7), 637-654.

West, S. G., Finch, J. F., \& Curran, P. J. (1995). Structural equation models with non-normal variables: Problems and remedies. In R. H. Hoyle (Ed.), Structural equation modeling: Concepts, issues and applications (pp. 56-75). Newbery Park, CA: Sage.

Woisetschläger, D. M., \& Michaelis, M. (2012). Sponsorship congruence and brand image. European Journal of Marketing, 46(3/4), 509-523. 
Table 1

Descriptive Statistics of Sponsor-event Congruence, Event Emotions, Event Attitude, Sponsor Attitude, and Purchase Intention

\begin{tabular}{|c|c|c|c|c|c|c|}
\hline Construct & Item & $\mathrm{M}$ & $\mathrm{SD}$ & Skewness & Kurtosis & $\alpha$ \\
\hline \multirow{5}{*}{ Sponsor-event congruence } & Item 1 & 2.80 & 1.03 & 1.03 & -0.34 & .85 \\
\hline & Item 2 & 3.35 & 1.06 & 1.06 & -0.35 & \\
\hline & Item 3 & 3.15 & 1.04 & 1.04 & -0.47 & \\
\hline & Item 4 & 3.65 & 1.00 & 1.00 & 0.01 & \\
\hline & Item 5 & 2.55 & 1.05 & 1.05 & -0.69 & \\
\hline \multirow[t]{9}{*}{ Positive event emotions } & Item 1 & 3.94 & 0.66 & 0.66 & -0.18 & .71 \\
\hline & Item 2 & 3.48 & 0.79 & 0.79 & 0.67 & \\
\hline & Item 3 & 3.17 & 0.96 & 0.96 & 0.39 & \\
\hline & Item $4 *$ & 3.00 & 1.01 & 1.01 & -0.21 & \\
\hline & Item 5 & 4.00 & 0.84 & 0.84 & 1.08 & \\
\hline & Item 6 & 3.60 & 0.77 & 0.77 & 0.68 & \\
\hline & Item 7 & 3.07 & 0.97 & 0.97 & 0.38 & \\
\hline & Item 8 & 3.18 & 1.08 & 1.08 & -0.23 & \\
\hline & Item 9 & 3.54 & 0.87 & 0.87 & 0.38 & \\
\hline \multirow[t]{7}{*}{ Negative event emotions } & Item 1 & 1.72 & 0.79 & 0.79 & -0.57 & .78 \\
\hline & Item 2 & 2.35 & 0.96 & 0.96 & -0.82 & \\
\hline & Item 3 & 2.11 & 1.01 & 1.01 & -0.28 & \\
\hline & Item 4 & 2.09 & 1.05 & 1.05 & -0.45 & \\
\hline & Item 5 & 2.21 & 0.91 & 0.91 & -0.87 & \\
\hline & Item 6 & 2.07 & 0.93 & 0.93 & -0.42 & \\
\hline & Item 7 & 2.27 & 1.07 & 1.07 & -0.69 & \\
\hline \multirow[t]{7}{*}{ Attitude towards the event } & Item 1 & 3.19 & 0.87 & 0.87 & 0.21 & .83 \\
\hline & Item 2 & 3.88 & 0.76 & 0.76 & 0.15 & \\
\hline & Item 3 & 3.65 & 0.80 & 0.80 & 0.18 & \\
\hline & Item 4 & 3.62 & 0.81 & 0.81 & 0.55 & \\
\hline & Item 5 & 3.82 & 0.72 & 0.72 & -0.41 & \\
\hline & Item 6 & 3.92 & 0.73 & 0.73 & -0.26 & \\
\hline & Item 7 & 2.81 & 0.91 & 0.91 & 0.07 & \\
\hline \multirow{9}{*}{$\begin{array}{l}\text { Attitude towards the } \\
\text { sponsor }\end{array}$} & Item 1 & 3.54 & 0.85 & 0.85 & 1.03 & .92 \\
\hline & Item 2 & 3.58 & 0.90 & 0.90 & 0.43 & \\
\hline & Item 3 & 3.57 & 0.89 & 0.89 & 0.48 & \\
\hline & Item 4 & 3.16 & 0.94 & 0.94 & 0.16 & \\
\hline & Item 5 & 2.71 & 0.98 & 0.98 & -0.19 & \\
\hline & Item 6 & 3.24 & 0.87 & 0.87 & 0.42 & \\
\hline & Item 7 & 3.57 & 0.84 & 0.84 & 1.39 & \\
\hline & Item 8 & 3.01 & 0.97 & 0.97 & -0.16 & \\
\hline & Item 9 & 2.85 & 1.00 & 1.00 & -0.07 & \\
\hline \multirow[t]{4}{*}{ Purchase intention } & Item 1 & 2.67 & 0.95 & 0.95 & -0.42 & .89 \\
\hline & Item 2 & 2.55 & 0.91 & 0.91 & -0.46 & \\
\hline & Item 3 & 2.84 & 0.97 & 0.97 & -0.19 & \\
\hline & Item 4 & 2.97 & 0.90 & 0.90 & 0.54 & \\
\hline
\end{tabular}

*This item was removed after the reliability test due to its poor item-to-total correlation. 
Table 2

The Assessment of Internal Model fit

\begin{tabular}{|c|c|c|c|}
\hline Construct & Measures & Loading & AVE \\
\hline \multirow{5}{*}{$\begin{array}{l}\text { Sponsor- } \\
\text { event } \\
\text { congruence }\end{array}$} & Surf n Sweat tells me something about Red Bull. & .79 & \multirow{5}{*}{.54} \\
\hline & It is clear which brand is sponsored for. & .74 & \\
\hline & The image of Red Bull is in accordance with the image of Surf $n$ & .85 & \\
\hline & $\begin{array}{l}\text { Sweet. } \\
\text { There is a natural fit between Surf } n \text { Sweet and what Red Bull } \\
\text { stands for. }\end{array}$ & .65 & \\
\hline & $\begin{array}{l}\text { I have learned something new about Red Bull by participating in } \\
\text { Surf n Sweat. }\end{array}$ & .62 & \\
\hline \multirow{9}{*}{$\begin{array}{l}\text { Positive } \\
\text { event } \\
\text { emotions }\end{array}$} & Joy & .51 & \multirow{9}{*}{.23} \\
\hline & Success & .57 & \\
\hline & Pretty & .49 & \\
\hline & Stimulation & .31 & \\
\hline & Healthy & .56 & \\
\hline & Fine & .49 & \\
\hline & Wanted & .49 & \\
\hline & Expectation & .46 & \\
\hline & Fresh & .39 & \\
\hline \multirow{7}{*}{$\begin{array}{l}\text { Negative } \\
\text { event } \\
\text { emotions }\end{array}$} & Sad & .60 & \multirow{7}{*}{.36} \\
\hline & Critical & .49 & \\
\hline & Annoyed & .63 & \\
\hline & Boring & .45 & \\
\hline & Doubt & .75 & \\
\hline & Worry & .79 & \\
\hline & Pain & .41 & \\
\hline \multirow{7}{*}{$\begin{array}{l}\text { Attitude } \\
\text { towards the } \\
\text { event }\end{array}$} & Surf $n$ Sweat included brand information relevant to me. & .43 & \multirow{7}{*}{.46} \\
\hline & It was entertaining to participate in Surf $n$ Sweat. & .71 & \\
\hline & Surf $n$ Sweat succeeded in involving me. & .75 & \\
\hline & Surf $n$ Sweat was well arranged. & .73 & \\
\hline & I will be pleased to recommend Surf $n$ Sweat to others. & .86 & \\
\hline & I am interested in activities Surf $n$ Sweat offered. & .77 & \\
\hline & Surf $n$ Sweat has increased my interest in Red Bull. & .29 & \\
\hline \multirow{9}{*}{$\begin{array}{l}\text { Attitude } \\
\text { towards the } \\
\text { sponsor }\end{array}$} & I think that Red Bull is a good brand. & .69 & \multirow{9}{*}{.57} \\
\hline & $\begin{array}{l}\text { I think that Red Bull has some advantageous characteristics } \\
\text { compared to other similar brands within the relevant product } \\
\text { category (e.g., Monster). }\end{array}$ & .73 & \\
\hline & I have a positive attitude towards Red Bull. & .85 & \\
\hline & Buying Red Bull is a good decision. & .85 & \\
\hline & $\begin{array}{l}\text { I am willing to pay a higher price for Red Bull than for other } \\
\text { similar products within the product category. }\end{array}$ & .65 & \\
\hline & $\begin{array}{l}\text { Red Bull is better of quality than other similar brands within the } \\
\text { product category. }\end{array}$ & .79 & \\
\hline & I think that Red Bull is a reliable and credible brand. & .74 & \\
\hline & I am interested in Red Bull. & .78 & \\
\hline & I am interested in knowing more about Red Bull. & .69 & \\
\hline \multirow{4}{*}{$\begin{array}{l}\text { Purchase } \\
\text { intention }\end{array}$} & Red Bull is personally relevant to me. & .82 & \multirow{4}{*}{.66} \\
\hline & $\begin{array}{l}\text { Surf n Sweat gave me information about a new Red Bull product } \\
\text { that I would like to try out. }\end{array}$ & .68 & \\
\hline & I would likely buy Red Bull's products. & .91 & \\
\hline & I would recommend Red Bull to others. & .83 & \\
\hline
\end{tabular}


Table 3

Correlations among the Latent Variables

\begin{tabular}{|c|c|c|c|c|c|c|}
\hline & Congruence & $\begin{array}{c}\text { Positive } \\
\text { event } \\
\text { emotions }\end{array}$ & $\begin{array}{c}\text { Negative } \\
\text { event } \\
\text { emotions }\end{array}$ & $\begin{array}{l}\text { Attitude } \\
\text { towards the } \\
\text { event }\end{array}$ & $\begin{array}{c}\text { Attitude } \\
\text { towards the } \\
\text { sponsor }\end{array}$ & $\begin{array}{l}\text { Purchase } \\
\text { Intention }\end{array}$ \\
\hline Congruence & .73 & & & & & \\
\hline $\begin{array}{l}\text { Positive event } \\
\text { emotions }\end{array}$ & .31 & .48 & & & & \\
\hline $\begin{array}{l}\text { Negative event } \\
\text { emotions }\end{array}$ & .08 & .03 & .60 & & & \\
\hline $\begin{array}{l}\text { Attitude towards the } \\
\text { event }\end{array}$ & .22 & .73 & -.06 & .68 & & \\
\hline $\begin{array}{l}\text { Attitude towards the } \\
\text { sponsor }\end{array}$ & .07 & .24 & -.02 & .33 & .76 & \\
\hline Purchase intention & .06 & .20 & -.02 & .27 & .82 & .81 \\
\hline
\end{tabular}


Table 4

Path Coefficients for the Proposed Relationships

\begin{tabular}{lllc}
\hline Endogenous variable & Exogenous variable & $\beta$ & $t$ \\
\hline Negative event emotions & Sponsor-event congruence (H1) & .08 & 1.06 \\
Positive event emotions & Sponsor-event congruence (H2) & $.31^{*}$ & 3.56 \\
Attitude towards the event & Positive event emotions (H3) & $.73^{*}$ & 4.71 \\
& Negative event emotions (H4) & .08 & -1.30 \\
Attitude towards the sponsor & Attitude towards the event (H5) & $.33^{*}$ & 3.78 \\
Purchase intention & Attitude towards the sponsor (H6) & $.82^{*}$ & 9.82 \\
\hline
\end{tabular}

*Significant at $p<.05$. 


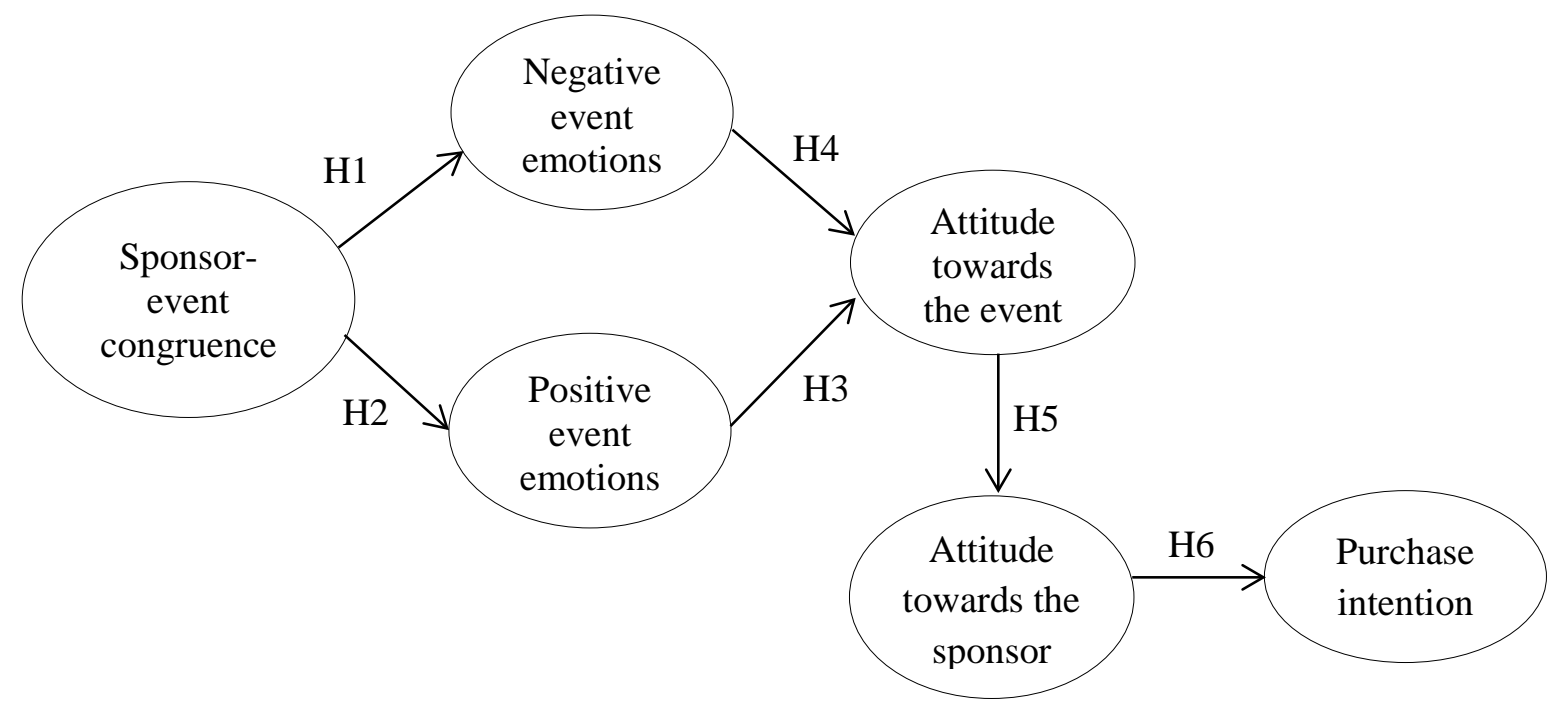

Figure 1. A proposed model for brand image transfer through event sponsorship. 